\title{
Novel Exploratory Spatiotemporal Analysis to Identify Sociospatial Patterns at Small Areas Using Property Transaction Data in Dublin
}

\author{
Hamidreza Rabiei-Dastjerdi *D and Gavin McArdle (1D \\ School of Computer Science and CeADAR, University College Dublin, Dublin 4, Ireland; gavin.mcardle@ucd.ie \\ * Correspondence: hamid.rabiei@ucd.ie
}

check for

updates

Citation: Rabiei-Dastjerdi, H.; McArdle, G. Novel Exploratory Spatiotemporal Analysis to Identify Sociospatial Patterns at Small Areas Using Property Transaction Data in Dublin. Land 2021, 10, 566. https:// doi.org/10.3390/land10060566

Academic Editors: Mirosław Bełej, Małgorzata Krajewska and Izabela Rącka

Received: 19 April 2021

Accepted: 25 May 2021

Published: 28 May 2021

Publisher's Note: MDPI stays neutral with regard to jurisdictional claims in published maps and institutional affiliations.

Copyright: (c) 2021 by the authors. Licensee MDPI, Basel, Switzerland. This article is an open access article distributed under the terms and conditions of the Creative Commons Attribution (CC BY) license (https:// creativecommons.org/licenses/by/ $4.0 /)$.

\begin{abstract}
The residential real estate market is very important because most people's wealth is in this sector, and it is an indicator of the economy. Real estate market data in general and market transaction data, in particular, are inherently spatiotemporal as each transaction has a location and time. Therefore, exploratory spatiotemporal methods can extract unique locational and temporal insight from property transaction data, but this type of data are usually unavailable or not sufficiently geocoded to implement spatiotemporal methods. In this article, exploratory spatiotemporal methods, including a space-time cube, were used to analyze the residential real estate market at small area scale in the Dublin Metropolitan Area over the last decade. The spatial patterns show that some neighborhoods are experiencing change, including gentrification and recent development. The extracted spatiotemporal patterns from the data show different urban areas have had varying responses during national and global crises such as the economic crisis in 2008-2011, the Brexit decision in 2016, and the COVID-19 pandemic. The study also suggests that Dublin is experiencing intraurban displacement of residential property transactions to the west of Dublin city, and we are predicting increasing spatial inequality and segregation in the future. The findings of this innovative and exploratory data-driven approach are supported by other work in the field regarding Dublin and other international cities. The article shows that the space-time cube can be used as complementary evidence for different fields of urban studies, urban planning, urban economics, real estate valuations, intraurban analytics, and monitoring sociospatial changes at small areas, and to understand residential property transactions in cities. Moreover, the exploratory spatiotemporal analyses of data have a high potential to highlight spatial structures of the city and relevant underlying processes. The value and necessity of open access to geocoded spatiotemporal property transaction data in social research are also highlighted.
\end{abstract}

Keywords: real estate market; residential property; exploratory spatiotemporal analysis; small area; Dublin

\section{Introduction}

The real estate market is attractive from different perspectives to analyze urban problems such as spatial inequality [1,2], gentrification [3], land development [4], and urban economy [5]. Housing prices are not constant in all areas of the city, and intraurban variation of residential properties price is determined by different characteristics of the location, including urban facilities and services, environmental and socioeconomic conditions, and security and safety [6,7]. On the other hand, the property price is changing over time because of changes in endogenous and exogenous factors such as the local and national economy [8-10], urban policy [11], macro-economic factors such as financial crises [12], world real estate economy, and stock markets [13]. Therefore, we can conclude that location and time of residential property transactions are two of the primary components of a residential property price if all other building characteristics are constant such as the size of the building and the lot, the number of rooms, and energy system [14]. 
Having both spatial and temporal components allows researchers to explore and understand locational and temporal changes and reactions of the real estate market to space and time variations [15]. The aim of this article is to explore the potential of residential property transaction data (collected from Property Services Regulatory Authority's (PSRA) website (http:/ / psr.ie/; accessed on 16 May 2021) to identify neighborhood change in Dublin and to address the following analytical research questions using exploratory spatiotemporal methods.

- What are the spatiotemporal patterns of the distribution of residential property transactions in Dublin over the last decade?

- Can residential property transaction data be used to identify neighborhood changes in the city?

- Which areas in the city have been attractive for real estate market activity?

The remainder of this article is structured as follows. Section 2 presents a literature review and discusses related research on spatial data analysis of residential property transactions and their link with the characteristics of a neighborhood. As the focus of this article is on the exploratory spatiotemporal analysis of residential property transactions in Dublin over the last decade, existing theories are not discussed in detail. Section 3, Materials and Methods, presents an overview of the residential property price data and the implementation used in this research. Section 4 presents the extracted spatial information and patterns from the transaction data. Finally, Section 5 presents the conclusions of this study and provides some suggestions for future research in the field.

\section{Literature Review and Background}

The real estate market is an indicator of housing policies and significantly affects many aspects of urban life for all people because urban planning and government systems play a crucial role in housing demand and supply through short- and long-term housing plans such as social housing, zoning, and local and national development plans [16]; as they are twin urban processes that shape the sociospatial structure of the city [17]. It means we can see the consequences and footprints of urban and property development in the real estate market.

At the small area or local level, the real estate market is a constant and significant component of any type of neighborhood change [18]. Neighborhood or location has various socioeconomic, political, physical, and environmental characteristics (e.g., accessibility to urban facilities and services, public open spaces, and socioeconomic conditions) [6,7,19]. As many scholars identified, the real estate market or housing price has two main categories, including building characteristics, e.g., size and age, and neighborhood or location characteristics, e.g., socioeconomic condition and accessibility to urban facilities and services $[6,20]$. The effect of the characteristics of location or neighborhood on the housing market was studied from different perspectives, such as housing price and affordability [21,22]. Also, the spatial variability of housing prices in different urban areas is well established in the literature. It is an indicator of differentiation in intraurban quality of the urban built-environment, socioeconomic conditions, crime rate, and housing policy in different locations or neighborhoods in the city [23-30]. In other words, the housing market and price are being influenced by a series of socioeconomic, environmental, political, planning, and demographic factors on the one hand, while housing price can affect these factors directly and indirectly [29]. The housing market, as the most significant determinant factor of land use and population density [31], shapes the urban structure, morphology, and form at the same time [32-34].

Any type of change in characteristics of a neighborhood or neighborhood change [6,35] can be traced back to the real estate market, especially price change [36]. Therefore, housing price, an index of housing market performance, can be used as a proxy of neighborhood change and as an indicator of changes in characteristics of locations in the city.

In addition, the number of housing market transactions is more sensitive to macro factors of the economy in comparison with housing price and GDP [37]. The number of 
housing market transactions is also influenced by housing price and availability of credit or mortgage approvals $[38,39]$. Geographical translation of this index or spatial index of the number of transactions can be seen as a proxy for supply and demand of housing within an area. From an economic perspective, if the number of the transaction changes dramatically, it is a shift in supply and demand curves in that location or neighborhood. Therefore, it can be concluded that any shift in supply and demand curves can lead to or be the outcome of a type of change in socioeconomic and physical characteristics of a neighborhood or neighborhood change [35] regardless of the internal or external causing factors. Finally, if this change is consistent with a similar change pattern in house prices in a neighborhood it reveals a type of upgrading or decaying neighborhood change such as gentrification and supergentrification, or a sign of a recently developed area [35].

This study explores statistical, spatial, temporal, spatiotemporal patterns in registered residential property transaction data in Dublin (as a case study) during the last decade from 2010 to 2020 to investigate the potential application of the Space-Time Cube (STC) and Emerging Hotspott Analysis (EHA) Toolbox for researchers with minimum technical skills to identify locations of neighborhood change.

\section{Materials and Methods}

\subsection{Data}

The data are publicly available from the Property Services Regulatory Authority (PSRA) website in a spreadsheet. The registered residential properties price, which includes the addresses of the residential properties and the time and price of the transactions, was geocoded using Geodriectory data in the Dublin Metropolitan Area, including the postal districts of Dublin and the North the South County areas (Figure 1). Table 1 shows the number of geocoded property transaction points based on the date and their postal code in Dublin, including 24 postal districts of Dublin, the North County (NC), and the South County (SC).

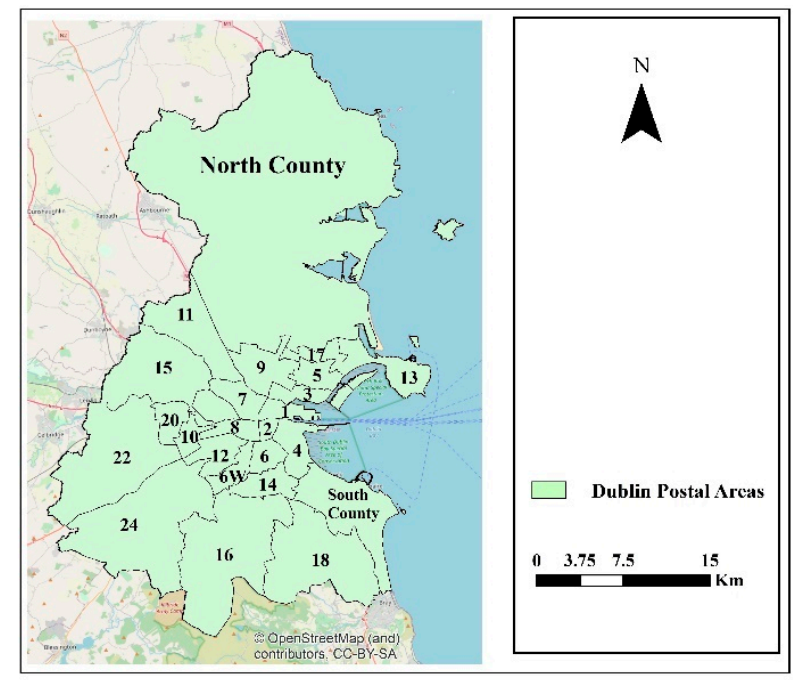

Figure 1. Dublin Postal Areas. 
Table 1. Number of Registered Residential Property Transaction Based on the Location and Time.

\begin{tabular}{|c|c|c|c|c|c|c|c|c|c|c|c|c|}
\hline \multirow[b]{2}{*}{ Postal Area } & \multicolumn{11}{|c|}{ Date } & \multirow[b]{2}{*}{$\begin{array}{c}\text { Grand } \\
\text { Total }\end{array}$} \\
\hline & 2010 & 2011 & 2012 & 2013 & 2014 & 2015 & 2016 & 2017 & 2018 & 2019 & 2020 & \\
\hline Dublin 1 & 83 & 97 & 424 & 597 & 1536 & 1568 & 381 & 366 & 309 & 315 & 165 & 5841 \\
\hline Dublin 2 & 21 & 20 & 71 & 124 & 188 & 197 & 205 & 117 & 98 & 80 & 35 & 1156 \\
\hline Dublin 3 & 143 & 153 & 238 & 261 & 346 & 395 & 289 & 282 & 306 & 282 & 177 & 2872 \\
\hline Dublin 4 & 160 & 194 & 559 & 488 & 569 & 556 & 794 & 492 & 462 & 449 & 267 & 4990 \\
\hline Dublin 5 & 139 & 170 & 245 & 221 & 279 & 292 & 278 & 305 & 292 & 338 & 186 & 2745 \\
\hline Dublin 6 & 160 & 181 & 367 & 393 & 458 & 506 & 489 & 484 & 474 & 380 & 225 & 4117 \\
\hline Dublin 6W & 167 & 122 & 193 & 253 & 425 & 347 & 273 & 233 & 245 & 219 & 139 & 2616 \\
\hline Dublin 7 & 232 & 177 & 422 & 451 & 688 & 678 & 624 & 493 & 501 & 581 & 338 & 5185 \\
\hline Dublin 8 & 159 & 137 & 303 & 371 & 499 & 606 & 432 & 442 & 447 & 416 & 238 & 4050 \\
\hline Dublin 9 & 292 & 252 & 485 & 542 & 751 & 841 & 684 & 584 & 609 & 743 & 348 & 6131 \\
\hline Dublin 10 & 44 & 49 & 108 & 96 & 107 & 119 & 116 & 112 & 107 & 111 & 71 & 1040 \\
\hline Dublin 11 & 75 & 67 & 243 & 230 & 205 & 338 & 225 & 264 & 265 & 276 & 153 & 2341 \\
\hline Dublin 12 & 218 & 207 & 338 & 364 & 392 & 448 & 445 & 410 & 409 & 441 & 269 & 3941 \\
\hline Dublin 13 & 150 & 115 & 213 & 348 & 428 & 361 & 310 & 309 & 338 & 329 & 194 & 3095 \\
\hline Dublin 14 & 218 & 222 & 364 & 386 & 469 & 498 & 431 & 522 & 494 & 405 & 275 & 4284 \\
\hline Dublin 15 & 343 & 263 & 547 & 688 & 834 & 1009 & 1020 & 1083 & 1028 & 994 & 485 & 8294 \\
\hline Dublin 16 & 177 & 140 & 310 & 330 & 451 & 553 & 474 & 355 & 379 & 390 & 194 & 3753 \\
\hline Dublin 17 & 66 & 54 & 152 & 144 & 236 & 209 & 195 & 148 & 127 & 128 & 72 & 1531 \\
\hline Dublin 18 & 158 & 120 & 345 & 361 & 665 & 748 & 444 & 411 & 394 & 318 & 205 & 4169 \\
\hline Dublin 20 & 56 & 57 & 112 & 106 & 132 & 162 & 137 & 135 & 134 & 168 & 84 & 1283 \\
\hline Dublin 22 & 425 & 241 & 454 & 523 & 796 & 706 & 651 & 620 & 856 & 833 & 516 & 6621 \\
\hline Dublin 24 & 282 & 165 & 375 & 535 & 617 & 843 & 585 & 671 & 696 & 849 & 411 & 6029 \\
\hline N County & 478 & 346 & 816 & 986 & 1762 & 2031 & 1449 & 1430 & 1518 & 1698 & 928 & 13,442 \\
\hline S County & 437 & 509 & 1089 & 1185 & 1433 & 1513 & 1250 & 1093 & 1023 & 972 & 607 & 11,111 \\
\hline Grand T & 4683 & 4058 & 8773 & 9983 & 14,266 & 15,524 & 12,181 & 11,361 & 11,511 & 11,715 & 6582 & 110,637 \\
\hline
\end{tabular}

\subsection{Methodology}

In this article, temporal, spatial, and spatiotemporal methods were used to explore spatial, temporal, and spatiotemporal patterns in the property transactions data in Dublin. For temporal analysis, the median price of properties and the number of transactions in the last decade were explored. Firstly, to remove outliers in the price data, a percentile-based method [40] was used to exclude the upper and lower five percent of records. Then, the median house price and the number of transactions were visualized to show the temporal changes of housing price and the number of transactions. Also, temporal changes were visualized for each postal code in Dublin to present spatial fragmentation of these two variables within the city.

There are different methods of interpolation to create a continuous surface from point data such as inverse distance weighting (IDW), Spline, and Kriging [41,42]. Kriging has several models including ordinary, simple, universal kriging, indicator Kriging, probability, disjunctive, and empirical Bayesian Kriging [41]. In this research, to produce a continuous map of housing prices from point data in the city, the ordinary Kriging interpolation method [43] as a common interpolation method [44] was used. The ordinary Kriging model is used to estimate the value of a point in a neighborhood over a continuous surface by using the values $\left(Z_{i}\right)$ of a limited set of (sampling) points $(n)$ in the same neighborhood [45]. This interpolation method estimates the value of an unknown point $(\hat{Z})$ based on a weighted sum $\left(W_{i}\right)$ of the values $\left(Z_{i}\right)$ of known (sampling) points or observations $(n)$ in a neighborhood [41] (see Equation (1)).

$$
\hat{Z}=\sum_{n=1}^{n}\left(W_{i} \times Z_{i}\right)
$$


The weighted sum $\left(W_{i}\right)$ is calculated for each sampling point or observation based on its distance from the points, is used to estimate its value, using covariances between sampling points. The sum of weights is equal to 1 (Equation (2)); more detail can be found in [45-47].

$$
\sum_{n=1}^{n}\left(W_{i}\right)=1
$$

Space-Time Cube (STC), Emerging Hotspot Analysis (EHA) methods, and ArcGIS Desktop and Pro software have been used. STC is based on time geography or timespace geography introduced by Hägerstrand [48] to extract spatiotemporal patterns in the data [49] or to understand the movement of objects through space and time [50]. STC transforms data into a cube with three axes which are longitudinal, latitudinal, and temporal axes, respectively, and counts the number of points in equal bins of this cube (Figure 2) [35]. In this research, $x$ and $y$ identify the location of transactions, and $z$ is the time of registered property transactions in that location or area of the city.

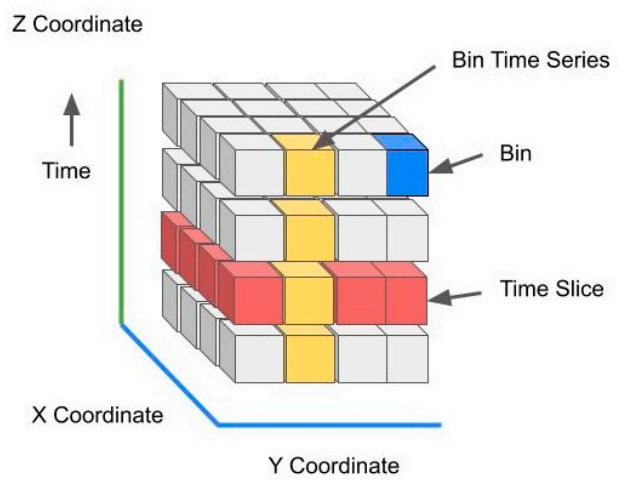

Figure 2. Example of bin use in the Space-Time Cube Paradigm.

EHA, in the first step, calculates Getis-Ord $G_{i}^{*}$ [42] or hotspots and coldspots of property transactions using Equations (3)-(5).

$$
\begin{gathered}
G_{i}^{*}=\frac{\sum_{j=1}^{n} w_{i, j} x_{j}-\bar{X} \sum_{j=1}^{n} w_{i, j}}{S \sqrt{\frac{\left[n \sum_{j=1}^{n} w_{i, j}^{2}-\left(\sum_{j=1}^{n} w_{i, j}\right)^{2}\right]}{n-1}}} \\
\bar{X}=\frac{\sum_{j=1}^{n} x_{j}}{n} \\
S=\sqrt{\frac{\sum_{j=1}^{n} x_{j}^{2}}{n}-(\bar{X})^{2}}
\end{gathered}
$$

where:

$G_{i}^{*}$ is the spatial dependency of a variable at location $i$;

$n$ is all number of sampling points or property transactions;

$x_{j}$ is the value of $X$ at location $j$;

$w_{i, j}$ is the weight value between properties $i$ and $j$.

The next step of EHA is using the Mann-Kendall [51] test to identify spatial and statistical patterns in previously calculated Getis-Ord $G_{i}{ }^{*}$ statistics (hotspots and coldspots of property transactions). More details of the Mann-Kendall test and EHA can be found in $[35,49,51]$.

STC and EHA are user-friendly Toolboxes in ArcGIS (Desktop and Pro) software for researchers with minimum technical skills in different fields of urban studies. Both Toolboxes have been used in other studies to extract various spatiotemporal patterns of urban crime [52], Airbnb [35], pedestrian density [53], urban green spaces in urban areas. 


\section{Results and Discussion}

\subsection{Results}

Figure 3 shows the median price (thousand Euros) and the number of property transactions over the last decade in the Dublin postal code areas. Figure 3a shows that the median price of properties has been increasing since 2012 after the recession [54]. Figure 3b shows that the number of transactions has increased after the recession and hits the peak in 2015 , and after that, it started decreasing in 2016. Also, there is a sharp decline beginning in 2019 to 2020.

The results have shown that the median price of properties in Dublin (Figure 3a) has increased constantly since the Irish housing crisis (bubble) when the median price reached the minimum point in 2012. The decrease in the price of properties started in 2007, after hitting the peak of price in 2006, during the Euro Debt Crisis [55], which led to a recession in Ireland [54]. The number of property transactions has been more sensitive to endogenous and exogenous factors of the economy (Figure $3 b$ ). This crisis had a longer impact on the real estate market until 2015. Also, the response of different areas especially the better off and the poorer areas, and the city center, to the macro factors (e.g., global and European crisis and COVID-19) and micro factors (e.g., housing development plans) of the economy are various in terms of the number of transactions (Figure 3c,d).

In contrast with some predictions, the number of transactions started falling after Brexit, withdrawal of Britain from the European Union and European Atomic Energy Community (EAEC or Euratom) after a referendum in June 2016 [56]. It shows heavy integration of the Irish economy and the British economy, but some research predicted the negative effect of Brexit on the Irish economy [57]. This falling pattern continues in 2020 due to the impacts of COVID-19 as many people and employees have been moving to the smaller cities close to or even far from Dublin and have been working from home since the start of the first national restrictions and lockdown in March 2020.

Figure $3 \mathrm{a}, \mathrm{b}$ highlight the impact of external factors on the property market in Dublin. Our interest is to identify if this impact is felt equally in different subareas of the city and at the same time. Figure $3 c, d$ confirm the existence of spatial heterogeneity of property price and the number of transactions in Dublin. These heterogeneities are influenced by characteristics of neighborhood and supply and demand in those neighborhoods. Based on this chart, Dublin 6 has the highest median price, and Dublin 10 has kept the minimum median price among all postal areas in Dublin. Figure 3d demonstrates that the number of transactions has been fluctuating in different urban areas, especially in Dublin 1 and North County Dublin, a leading area in the number of transactions since 2014. Dublin 15 and South Country Dublin also exhibit a similar pattern. Figure 3c,d show us which postal areas have been more prone to neighborhood change regardless of the causing factor and underlying processes or if they have reacted differently to internal and external factors during this period. e.g., Dublin 1, which has experienced a dramatic change in the number of transaction and Dublin 4 where the median price of this area has fluctuated several times based on the assumption that the median price of properties is the leading indicator of neighborhood change.

Figure 4 shows the number of registered new (primary-market) and secondarymarket properties transaction data in different urban areas. We can see that the real estate market is focused on secondary-market houses and apartments, and the number of new houses/apartments (primary-market) is low in comparison. This figure shows that the transactions of new properties are concentrated in Dublin 16, Dublin 18, Dublin 22, Dublin 24, and North and South Counties. Recently developed neighborhoods are within these areas. Simply put, the number of new properties in an area can identify an area that is prone to a type of neighborhood change. For example, gentrification and supergentrification, can occur in those areas that the number of new houses is low, yet sales are increasing, including Dublin 2, Dublin 3, Dublin 7, and Dublin 10, and Dublin 20, and recently developed change can happen in Dublin16, Dublin18, Dublin 22, Dublin 24, and North and South Counties. In addition, this gap identifies that many properties in Dublin are not primary- 
market properties; in other words, the number of new properties is limited to specific areas in the city. Figure 4 shows that the number of new property sales is significantly less than the secondary market. Considering residential property transactions as a proxy of the total number and types of properties in Dublin, it is safe to say that properties are aging. The reasons behind the lack of new houses are many, including financial problems, a lack of developers after the recession, and a slow planning permission process. A recently published report (https://www.datawrapper.de/_/fXLxZ/; accessed on 16 May 2021) using data from the Central Statistics Office (CSO) (https: / / www.cso.ie/;accessed on 16 May 2021) confirms that a large number of residential properties in Dublin are old. This report shows Dublin 15, Dublin18, and Dublin 24 are the youngest urban areas where the average age of buildings is 17,18 , and 22 years respectively, and the oldest buildings can be found in Dublin 3, Dublin 6, and Dublin 7 where the average age is 56,56 , and 58 respectively.

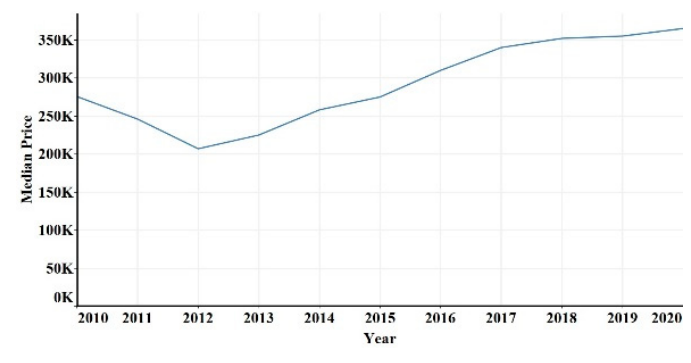

(a) Median Price (Euros)

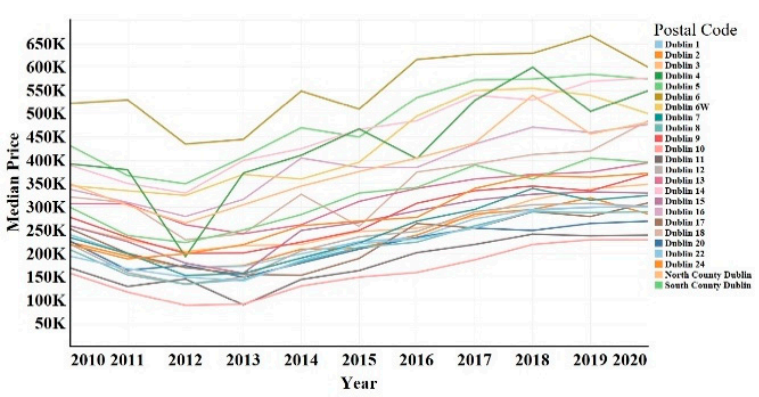

(c) Median Price (Euros) Based on Postal Code

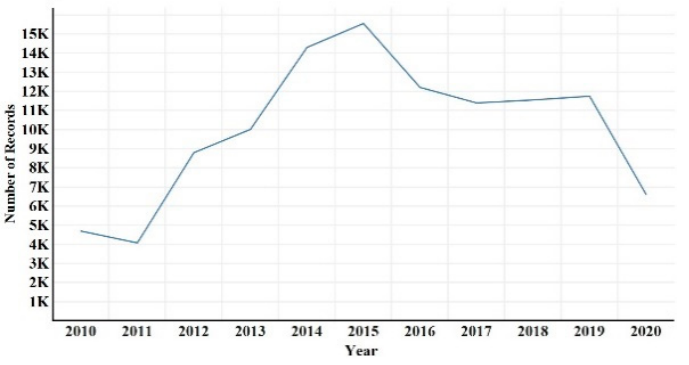

(b) Number of Transactions

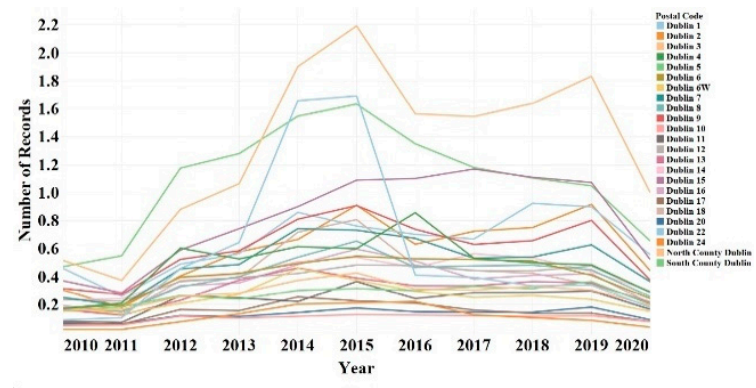

(d) Number of Transactions Based on Postal Code

Figure 3. Temporal Trends From 2010 to 2020 in Dublin.



Figure 4. Number of New (Primary-Market) and Secondary-Market Property Transactions in Postal Codes in Dublin. 
Figure 5 highlights the spatial coverage of property transactions in Dublin during the last decade, and we can see that the spatial distribution of transactions is uneven, and the concentration is in the city center and Dublin Bay, and along four axes to the west with some sporadic patches on the northern side of the city. The spatial distribution and density of the data also show that some neighborhoods have been more successful in absorbing people which have meaningful relationships with the urban infrastructure, affordable land and housing price, and recent development plans in Dublin. These relationships are confirmed by the median price and number of transactions in those areas (Figure 3c,d). Other urban areas that are not covered in this map or where we see sporadic points are locations where neighborhood change has not been significant during the last decade.



Figure 5. Spatial Patterns of Registered Property in Dublin.

The Kriging method [43] was used to interpolate property prices in Dublin over the last ten years. Figure 6 is the map of the registered property price in Dublin from 2019 to 2020. This map shows the average price (in Euros) of properties is high in Malahide, the Docklands, and the south-eastern part of the city, specifically in Dublin 2, Dublin 4, and Dublin 6. As the relationship between housing price and poverty is well established in the literature [30], this map is showing spatial structure and patterns of housing prices. It reflects the emerging spatial structure and patterns of inequalities, such asas the northsouth spatial divide and recently developed areas including Lucan, Ongar, and Adamstown and historic social housing plans and projects in the western part such as Jobstown, which is one of the most deprived areas in Dublin with a high unemployment rate and low rate of education [58]. In other words, this map draws existing and emerging spatial divides from east-north to west-south of the city.

Figure 7 shows the median price change in percent terms at small areas $(500 \times 500 \mathrm{~m}$ grid) produced by the Kriging interpolation method. The dark red color indicates locations with a higher percentage of price change that have been more attractive for investors and citizens and can be seen as the milieu of neighborhood changes such as gentrification, supergentrification, and recently developed areas or in general upgrading areas. In dark blue areas, the median price of properties decreased and are likely decaying neighborhoods. It should be taken into account that the output of interpolation methods is influenced by the number of existing sample points or the problem of sample size [59,60]. Therefore, the accuracy is higher in those areas that the number of samples is high, especially in the city center, and the accuracy of interpolation methods is low in areas at the fringe of the city because they are underrepresented locations in the data [60]. The results should therefore be interpreted with Figure 4. The accuracy and performance of the interpolation must be assessed using a proper validation model [61]. 


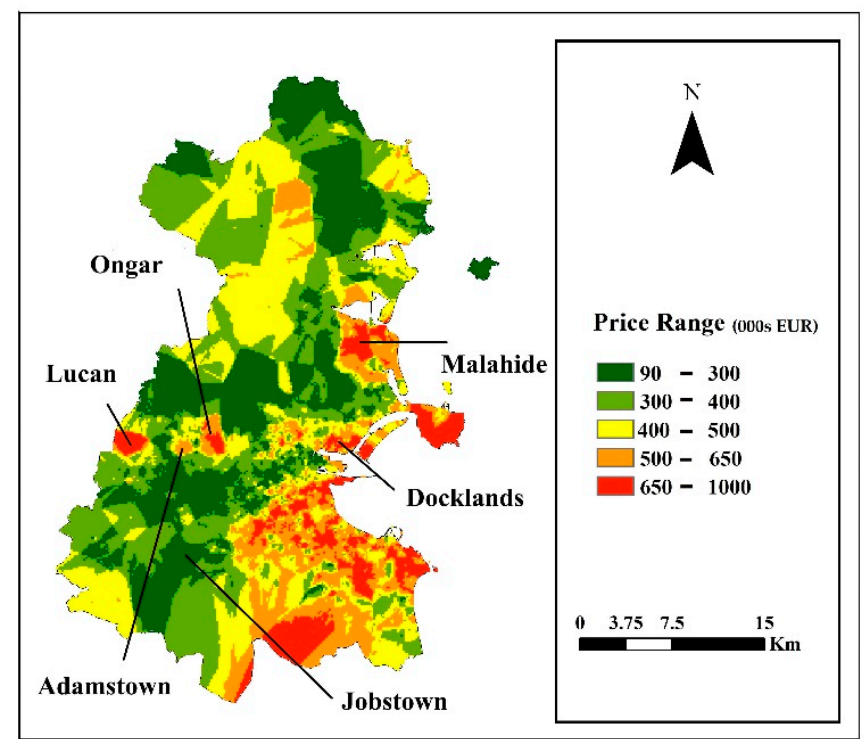

Figure 6. Price Reclassification Based on 2019 and 2020 in Dublin.



Figure 7. Price change from 2010 to 2020.

Figure 8 is the Z-score of housing transactions in Dublin in the different time periods at the small area scale of approximately $500 \mathrm{~m} \times 500 \mathrm{~m}$ grid sizes of the metropolitan area. Negative, positive, and zero values of Z-score indicate increasing patterns, decreasing patterns, and no pattern, respectively. Figure 8a shows that the number of transactions, from 2010 to 2011 in Dublin Bay and the south parts of the city, which are better off areas, were increasing (red color) locations, and the same areas were decreasing during the economic recovery from 2012 to 2015 (Figure 8b). From 2016 to 2017, we observe that some areas in the west and the south had increasing patterns, and the city center and south regions are experiencing decreasing patterns (Figure $8 \mathrm{c}$ ). Figure $8 \mathrm{~d}$ is the Z-score values during 2018. This figure shows that while almost all areas of the city are experiencing increasing patterns, some locations in the north and south display a decreasing pattern. 




(a). 2010-2011



(c). 2016-2017

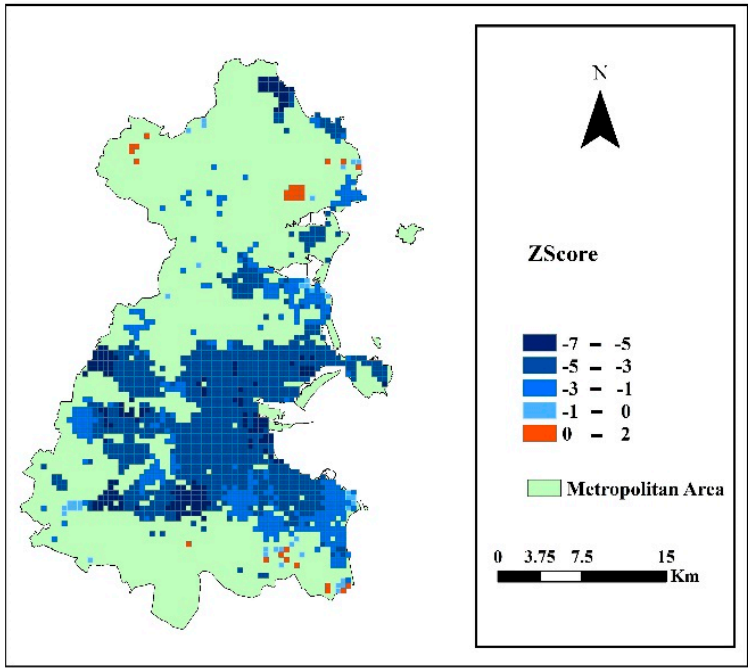

(e). 2019-2020



(b). 2012-2015

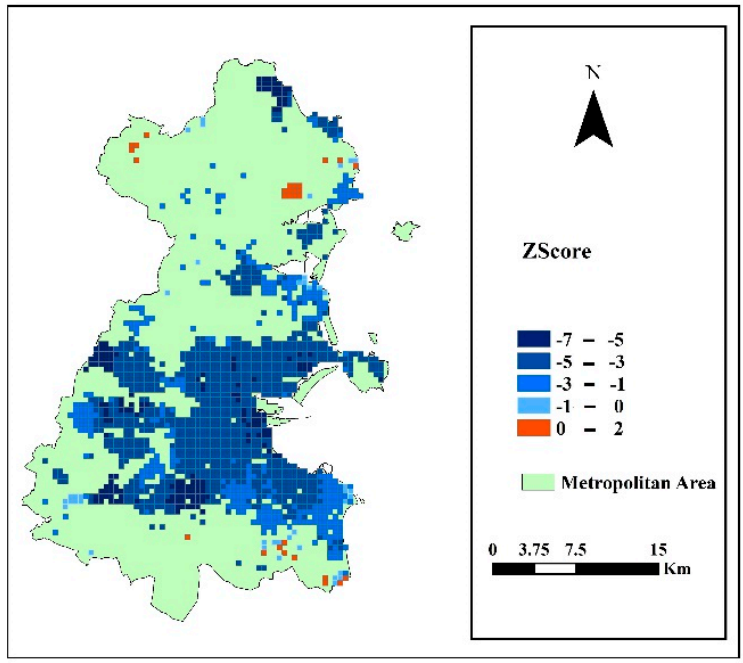

(d). 2018

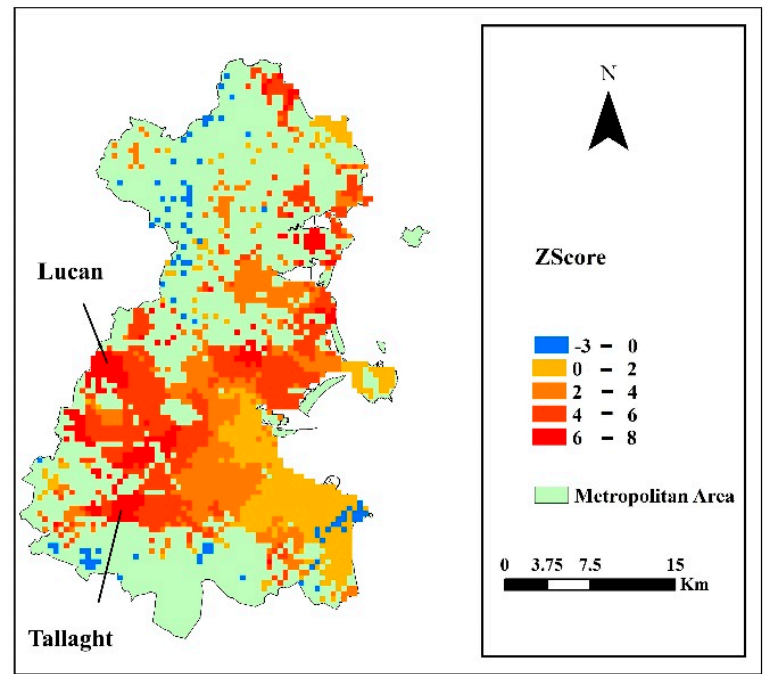

(f). 2010-2020

Figure 8. Z-Score of Number of Transaction in Different Time Periods. 
Figure 8e shows consecutive and oscillating cold spots (dark and light blue color), which mean, during this time, all urban areas are experiencing decreasing patterns in terms of the number of transactions, but in some areas in the city center close to the Docklands, on the west, and sporadic patches in the north the Z-score value is higher than other neighborhoods. Figure $8 \mathrm{f}$ is the Z-score values in the last decade from 2010 to 2020. This map shows that over the last decade, the focus of transactions has been in the city center, and hotspots have mainly moved to the west, including Tallaght, Lucan, the north, especially Malahide. In Figure 8, negative values are presented by blue color, and positive values are presented by red color. The intensity of the color is based on the value of the $\mathrm{Z}$-score; therefore, the color scales or ranges are different because the Z-score values are not the same for all time intervals.

Table 2 is the STC statistics for selected time periods. The Trend Direction is the direction of change in the number of property transactions in the real estate market. The Trend statistics show the intensity of change, and the P-value of the trend identifies the probability that a trend is the outcome of a random process or not.

Table 2. Space-Time Cube Statistics (2010-2020).

\begin{tabular}{ccccccc}
\hline Trend & $\mathbf{2 0 1 0 - 2 0 1 1}$ & $\mathbf{2 0 1 2 - 2 0 1 5}$ & $\mathbf{2 0 1 6 - 2 0 1 7}$ & $\mathbf{2 0 1 8}$ & $\mathbf{2 0 1 9 - 2 0 2 0}$ & $\mathbf{2 0 1 0 - 2 0 2 0}$ \\
\hline Direction & Not Significant & Increasing & Not Significant & Increasing & Decreasing & Increasing \\
Statistic & -0.85 & 6.99 & 0.39 & 3.34 & -4.74 & 3.16 \\
$p$-value & 0.39 & 0.00 & 0.69 & 0.00 & 0.00 & 0.00 \\
\hline
\end{tabular}

We also observe moving patterns of transactions from the east to the west in Dublin (Figures 4 and 8). These changes in spatial patterns of hotspots of the number of property transactions can be interpreted as people displacement or a move from the east and the center to the western parts of Dublin along with some sporadic locations in the north of the city where there are affordable houses (Figure 8). The results of the proposed data- driven methodology are consistent with other qualitative research and non-academic sources (e.g., media) on spatial inequality and neighborhood change in Dublin [58,62-71].

\subsection{Validation and Comparison of Results}

Table 3 lists the locations and neighborhoods that are identified by different sources as undergoing different types of neighborhood change (e.g., recently developed areas and gentrification) or areas that exhibit distinct spatial characteristics (e.g., concentration of poverty, spatial segregation, and affluent area). This serves to validate the data-driven approach presented in this article and demonstrates that it is appropriate in the absence of (or to support) qualitative analysis.

Table 3. Validation locations and evidence.

\begin{tabular}{cccc}
\hline No & Name & $\begin{array}{c}\text { Type of Neighborhood Change/ } \\
\text { Spatial Characteristics }\end{array}$ & Reference \\
\hline 1 & Lucan & Recently developed & {$[62,63]$} \\
2 & Ongar & Recently developed & {$[64]$} \\
3 & Adamstown & Recently developed & {$[62,65]$} \\
4 & Docklands & Gentrification & {$[66-68]$} \\
5 & Malahide & Affluent area & {$[69,70]$} \\
6 & Tallaght & Poverty and spatial segregation & {$[69,71]$} \\
7 & Jobstown & Poverty and spatial segregation & {$[58]$} \\
\hline
\end{tabular}

Table 4 shows zonal statistics of Z-score values from 2010-2020 (Figure 8f) in five price categories used in Figure 6 which shows the price of properties in Dublin based on Jenks natural breaks classification [72], where class 1 is the areas with the minimum median price, and class 5 has the highest median price. This table also includes the minimum, 
maximum, range, and mean values of Z-scores from 2010 to 2020 (Figure 8f). The column of Mean value Z-Score of this table, mean value of Z-Score during the last decade shows that a large number of transactions occurred in poorer locations, including classes 1 and class 2 (the lowest house price areas), which cover more than half of the urban area where transactions happened over the last decade. Class 3 as an indicator of middle-class or housing price areas has a mean value of 2.90, and high-class or the highest housing price areas (classes 4 and 5) have lower mean values of Z-score, respectively 2.55 and 1.78 . Briefly, the focus of the residential property market has mainly moved to the poor and the rich neighborhoods. This changing spatial pattern in the numbers of transactions can be interpreted as increasing spatial inequality in the city.

Table 4. Zonal Statistics of Z-score based on Five Price Categories in Dublin.

\begin{tabular}{ccccccc}
\hline Class & Area $\left.\mathbf{( m}^{\mathbf{2}}\right)$ & $\begin{array}{c}\text { Price Range } \\
\text { (000s EUR) }\end{array}$ & $\begin{array}{c}\text { Min } \\
\text { Z-Score }\end{array}$ & $\begin{array}{c}\text { Max } \\
\text { Z-Score }\end{array}$ & $\begin{array}{c}\text { Range } \\
\text { Z-Score }\end{array}$ & $\begin{array}{c}\text { Mean } \\
\text { Z-Score }\end{array}$ \\
\hline 1 & $55,190,000$ & $161.16-286.14$ & -1.82 & 8.01 & 9.83 & 4.87 \\
2 & $73,320,000$ & $286.14-375.86$ & -2.85 & 8.00 & 10.85 & 4.04 \\
3 & $66,770,000$ & $375.86-478.40$ & -1.88 & 8.00 & 9.88 & 2.90 \\
4 & $51,320,000$ & $478.40-629.00$ & -1.43 & 7.20 & 8.63 & 2.55 \\
5 & $23,540,000$ & $629.00-978.29$ & -0.32 & 6.34 & 6.66 & 1.78 \\
\hline
\end{tabular}

These moving patterns from the center to the periphery areas are seen in other large and global cities [73-78]. Van Ham et al. studied urban segregation and spatial inequality in 24 large urban case studies in Africa, Asia, Australia, Europe, North America, and South America. They found that affluent people are moving to the city center, while the people belonging to lower social class have been pushed to the outer edges of urban areas, and this observed spatiotemporal pattern is a reversal of the suburbanization trends of the 1970s, when many people of higher-income groups moved to bigger houses with gardens in the suburbs. These supporting results demonstrate that spatial data mining techniques and data-driven research can be used as a complement to other qualitative, quantitative, and mixed research methods [73,77].

\section{Conclusions}

The results presented in this article show that housing property transaction data, including price, time, and location of properties, are valuable spatiotemporal datasets to answer spatiotemporal research questions. The main findings of this article are summarized as follows:

- The housing market or housing price and the number of property transactions in Dublin are systematically influenced by macro factors of the national and European economy (e.g., Brexit) and global crises such as COVID-19. In the Irish context, the real estate market has been experiencing multiple crises and booming periods in the last decade and need effective housing policies [79].

- Spatiotemporal methods and techniques, especially STC, partitioning or reclassifying housing price and the number of property transactions, can reveal different urban spatial patterns and associated underlying socioeconomic processes at small areas and allow us to observe the effects of national and global crises and sociospatial (housing) policies. The study also shows that Dublin is experiencing intraurban displacement of the residential property transactions and citizens to more affordable regions of western areas, and we are observing increasing spatial inequality in Dublin as a result.

- Dublin is an old/aging city in terms of housing with relatively low numbers of houses being constructed. This attribute of the housing market needs more research and attention from urban managers and policy designers because the age of properties probably can have various unintentional consequences for all stakeholders and citizens in terms of energy consumption and maintenance cost [80]. Older properties usually 
do not have proper insulation and heating systems that are essential factors in energy consumption and budget [81].

Exploratory spatiotemporal analysis of property transaction data needs geocoded data, and the data is often available in spreadsheet format, but the geocoding process is costly and usually needs specific skills, reference data, and GIS software. Access to Geocoded data can facilitate using transaction data in various applications. While the focus of the literature is on property valuation, designing spatial decision support systems, market and housing price analysis, and automated valuation [82-85], this study has shown that property transaction data can be used in other research areas as well. The results of the study presented in this article can be used for the fields of urban studies, including urban planning, urban demography, urban economics, and urban analytics. For future research, the relationships between residential property transactions and Airbnb data, which is also publicly available through the InsideAirbnb (http:/ /insideairbnb.com/; accessed on 16 May 2021) website, can be studied. Also, advanced spatial econometrics [86,87] and machine learning methods, especially clustering algorithms [88], texture analysis (e.g., variability analysis and Fractal dimension [89]), and curve similarity within temporal graphs e.g., Fréchet distance $[90,91]$, can be used to extract locational insights and understand relationships between housing price and other locational factors such as the characteristics of neighborhoods and accessibility to the physical and environmental infrastructure of the city.

Besides these topics, relationships between the socioeconomic context using relevant indices and data sources such as Pobal (https:/ / www.pobal.ie/; accessed on 16 May 2021) in Ireland, which provide area deprivation profiles or spatial socioeconomic indices, can be studied. Other topics such as the fiscal policy and urban planning policies during the last decades, which are significant factors in shaping the real estate market and the (re)production of these spatiotemporal patterns, the north and south spatial divide, and spatial segregation and inequality in the city can also be examined. The techniques presented in this article can be applied to other jurisdictions where property transaction data are available.

Author Contributions: Conceptualization, G.M. and H.R.-D.; Data curation, H.R.-D.; Investigation, G.M. and H.R.-D.; Supervision, G.M.; Visualization, H.R.-D.; Writing-original draft, H.R.-D.; Writing - review \& editing, G.M. All authors have read and agreed to the published version of the manuscript.

Funding: Hamidreza Rabiei-Dastjerdi is a Marie Skłodowska-Curie Career-FIT Fellow at the UCD School of Computer Science and CeADAR (Ireland's National Centre for Applied Data Analytics \& AI). Career-FIT has received funding from the European Union's Horizon 2020 research and innovation programme under the Marie Skłodowska-Curie grant agreement No. 713654.

Informed Consent Statement: Not applicable.

Data Availability Statement: Not applicable.

Acknowledgments: The authors would like to thank the GeoDirecty company, especially Steven Grover, Head of Growth, who geocoded the PSRA data.

Conflicts of Interest: The authors declare no conflict of interest.

\section{References}

1. Rodríguez-Pose, A.; Storper, M. Housing, urban growth and inequalities: The limits to deregulation and upzoning in reducing economic and spatial inequality. Urban Stud. 2019, 57, 223-248. [CrossRef]

2. Shi, Q.; Dorling, D. Growing socio-spatial inequality in neo-liberal times? Comparing Beijing and London. Appl. Geogr. 2020, 115, 102139. [CrossRef]

3. López-Morales, E.J. Real estate market, state-entrepreneurialism and urban policy in the 'gentrification by ground rent dispossession' of Santiago de Chile. J. Lat. Am. Geogr. 2010, 9, 145-173. [CrossRef]

4. Shoup, D.C. The optimal timing of urban land development. Pap. Reg. Sci. Assoc. 1970, 25, 33-44. [CrossRef] 
5. McDonald, J.F.; McMillen, D.P. Urban Economics and Real Estate: Theory and Policy; John Wiley \& Sons: Hoboken, NJ, USA, 2010; ISBN 9780470591482.

6. Rabiei-Dastjerdi, H.; McArdle, G.; Matthews, S.A.; Keenan, P. Gap analysis in decision support systems for real-estate in the era of the digital earth. Int. J. Digit. Earth 2020, 14, 121-138. [CrossRef]

7. Sdino, L.; Rosasco, P.; Torrieri, F.; Oppio, A. A Mass Appraisal Model Based on Multi-criteria Evaluation: An Application to the Property Portfolio of the Bank of Italy. In International Symposium on New Metropolitan Perspectives; Springer: Cham, Switzerland, 2018; pp. 507-516.

8. Renigier-Biłozor, M.; Wisniewski, R.; Kaklauskas, A.; Biłozor, A. Rating Methodology for Real Estate Markets-Poland Case Study. Int. J. Strateg. Prop. Manag. 2014, 18, 198-212. [CrossRef]

9. Cellmer, R.; Cichulska, A.; Bełej, M. Spatial analysis of housing prices and market activity with the geographically weighted regression. ISPRS Int. J. Geo-Inf. 2020, 9, 380. [CrossRef]

10. Cellmer, R.; Cichulska, A.; Bełej, M. The Regional Spatial Diversity of Housing Prices and Market Activity-Evidence from Poland. Acta Sci. Pol. Adm. Locorum 2021, 20. [CrossRef]

11. Coiacetto, E. Real estate development industry structure: Consequences for urban planning and development. Plan. Pract. Res. 2006, 21, 423-441. [CrossRef]

12. Hartmann, P. Real Estate Markets and Macroprudential Policy in Europe. J. Money Credit Bank. 2015, 47, 69-80. [CrossRef]

13. Liow, K.H.; Webb, J.R. Common factors in international securitized real estate markets. Rev. Financ. Econ. 2009, 18, 80-89. [CrossRef]

14. Michelsen, C.C.; Madlener, R. Homeowners' preferences for adopting innovative residential heating systems: A discrete choice analysis for Germany. Energy Econ. 2012, 34, 1271-1283. [CrossRef]

15. Manco, G.; Baglioni, M.; Giannotti, F.; Kuijpers, B.; Raffaetà, A.; Renso, C. Querying and reasoning for spatiotemporal data mining. In Mobility, Data Mining and Privacy; Springer: Berlin/Heidelberg, Germany, 2008; pp. 335-374.

16. Gurran, N.; Bramley, G. (Eds.) Urban Planning and the Housing Market: International Perspectives for Policy and Practice; Palgrave Macmillan: London, UK, 2017; ISBN 978-1-137-46403-3.

17. Ratcliffe, J.; Stubbs, M.; Keeping, M. Urban Planning and Real Estate Development, 3rd ed.; Routledge: London, UK, 2009; ISBN 9780415450775.

18. Yuan, F.; Wu, J.; Wei, Y.D.; Wang, L. Policy change, amenity, and spatiotemporal dynamics of housing prices in Nanjing, China. Land Use Policy 2018, 75, 225-236. [CrossRef]

19. Oppio, A.; Bottero, M.; Dell'Anna, F.; Dell'Ovo, M.; Gabrielli, L. Correction to: Evaluating the Urban Quality through a Hybrid Approach: Application in the Milan (Italy) City Area. Comput. Sci. Appl. ICCSA 2020, 12253, C1.

20. Saphores, J.-D.; Li, W. Estimating the value of urban green areas: A hedonic pricing analysis of the single family housing market in Los Angeles, CA. Landsc. Urban Plan. 2012, 104, 373-387. [CrossRef]

21. Rahadi, R.A.; Wiryono, S.K.; Koesrindartoto, D.P.; Syamwil, I.B. Factors influencing the price of housing in Indonesia. Int. J. Hous. Mark. Anal. 2015, 8, 169-188. [CrossRef]

22. Kellett, J.; Morrissey, J.; Karuppannan, S. The impact of location on housing affordability. In Proceedings of the 6th Australasian Housing Researchers' Conference, Adelaide, Australia, 8-10 February 2012.

23. Richardson, H.W. Regional and Urban Economics; Penguin: London, UK, 1978; ISBN 0140809309.

24. Alonso, W. Location and Land Use. Toward a General Theory of Land Rent; Harvard University Press: Cambridge, MA, USA, 1964.

25. Helbich, M.; Brunauer, W.; Vaz, E.; Nijkamp, P. Spatial heterogeneity in hedonic house price models: The case of Austria. Urban Stud. 2014, 51, 390-411. [CrossRef]

26. Jackson, J.R. Intraurban variation in the price of housing. J. Urban Econ. 1979, 6, 464-479. [CrossRef]

27. Buonanno, P.; Montolio, D.; Raya-Vílchez, J.M. Housing prices and crime perception. Empir. Econ. 2013, 45, 305-321. [CrossRef]

28. Tita, G.E.; Petras, T.L.; Greenbaum, R.T. Crime and residential choice: A neighborhood level analysis of the impact of crime on housing prices. J. Quant. Criminol. 2006, 22, 299. [CrossRef]

29. Grigsby, W.G.; Rosenburg, L.S. Urban Housing Policy; Transaction Publishers: Piscataway, NJ, USA, $2012 ;$ ISBN 1412850584.

30. Rabiei-Dastjerdi, H.; Matthews, S.A. Who Gets What, Where, and How Much? Composite Index of Spatial Inequality at Small Area in Tehran. Reg. Sci. Policy Pract. 2021, 13, 191-205. [CrossRef]

31. Jones, C.; Leishman, C.; MacDonald, C. Sustainable urban form and residential development viability. Environ. Plan. A 2009, 41, 1667-1690. [CrossRef]

32. Williams, K.; Burton, E.; Jenks, M. Achieving Sustainable Urban Form; Routledge: London, UK, 2000; Available online: https: / / www.routledge.com/Achieving-Sustainable-Urban-Form/Burton-Jenks-Williams/p/book/9780419244509 (accessed on 16 May 2021).

33. Venables, A.J. Breaking into Tradables: Urban Form and Urban Function in a Developing City; The World Bank: Washington, DC, USA, 2017; ISBN 1813-9450.

34. Xiao, Y.; Webster, C. Urban Morphology and Housing Market; Springer: Berlin/Heidelberg, Germany, 2017 ; ISBN 9811027625.

35. Rabiei-Dastjerdi, H.; McArdle, G. Identifying Patterns of Neighbourhood Change Based on Spatiotemporal Analysis of Airbnb Data in Dublin. In Proceedings of the 4th International Conference on Smart Grid and Smart Cities (ICSGSC), Osaka, Japan, 18-21 August 2020; pp. 113-117. 
36. Bramley, G.; Leishman, C.; Watkins, D. Understanding neighbourhood housing markets: Regional context, disequilibrium, sub-markets and supply. Hous. Stud. 2008, 23, 179-212. [CrossRef]

37. Ortalo-Magne, F.; Rady, S. Housing Market Fluctuations in a Life-Cycle Economy with Credit Constraints. 1998. Available online: https:/ / ssrn.com/abstract=102933 (accessed on 16 May 2021).

38. Benito, A. The down-payment constraint and UK housing market: Does the theory fit the facts? J. Hous. Econ. 2006, 15, 1-20. [CrossRef]

39. Hay, C.; Smith, N. The story of a North Sea bubble: The strange demise of the Anglo-liberal growth model in the United Kingdom and Ireland. Eur. Political Sci. Rev. EPSR 2013, 5, 401. [CrossRef]

40. De Visser, J. The Impact of a Full Premier League-Takeover on House Prices. Master's Thesis, University of Groningen, Groningen, The Netherlands, 2021.

41. Stein, M.L. Interpolation of Spatial Data: Some Theory for Kriging; Springer Science \& Business Media: Berlin/Heidelberg, Germany, 2012; ISBN 1461214947.

42. Getis, A.; Ord, J.K. The analysis of spatial association by use of distance statistics. In Perspectives on Spatial Data Analysis; Springer: Berlin/Heidelberg, Germany, 2010; pp. 127-145.

43. Oliver, M.A.; Webster, R. Kriging: A method of interpolation for geographical information systems. Int. J. Geogr. Inf. Syst. 1990, 4, 313-332. [CrossRef]

44. Aumond, P.; Can, A.; Mallet, V.; de Coensel, B.; Ribeiro, C.; Botteldooren, D.; Lavandier, C. Kriging-based spatial interpolation from measurements for sound level mapping in urban areas. J. Acoust. Soc. Am. 2018, 143, 2847-2857. [CrossRef] [PubMed]

45. Wackernagel, H. Ordinary Kriging. In Multivariate Geostatistics; Wackernagel, H., Ed.; Springer: Berlin/Heidelberg, Germany, 1995; pp. 74-81. ISBN 978-3-662-03100-1.

46. Isaaks, E.H.; Srivastava, R.M. Applied Geostatistics; Oxford University Press: New York, NY, USA, 1989 ; p. 561.

47. Van Beers, W.; Kleijnen, J. Kriging Interpolation in Simulation: A Survey. In Proceedings of the IEEE 2004 Winter Simulation Conference, Agent of Change, Washington, DC, USA, 5-8 December 2004; ISBN 0780387864.

48. Hedley, N.R. Hagerstrand revisited: Interactive space-time visualizations of complex spatial data. Informatica 1999, 23, 155-168.

49. ESRI. Create Space Time Cube from Defined Locations (Space Time Pattern Mining). Available online: https://pro.arcgis.com/ en/pro-app/latest/tool-reference/space-time-pattern-mining/createcubefromdefinedlocations.htm (accessed on 16 May 2021).

50. Andrienko, G.; Andrienko, N.; Demsar, U.; Dransch, D.; Dykes, J.; Fabrikant, S.I.; Jern, M.; Kraak, M.-J.; Schumann, H.; Tominski, C. Space, time and visual analytics. Int. J. Geogr. Inf. Sci. 2010, 24, 1577-1600. [CrossRef]

51. McLeod, A.I. Kendall Rank Correlation and Mann-Kendall Trend Test. R Package Kendall 2005. Available online: http: //btr0x2.rz.uni-bayreuth.de/math/statlib/R/CRAN/doc/packages/Kendall.pdf (accessed on 16 May 2021).

52. Hashim, H.; Wan Mohd, W.M.; Sadek, E.; Dimyati, K.M. Modeling urban crime patterns using spatial space time and regression analysis. Int. Arch. Photogramm. Remote Sens. Spat. Inf. Sci. 2019, XLII-4/W16, 247-254. [CrossRef]

53. Petrasova, A.; Hipp, J.A.; Mitasova, H. Visualization of pedestrian density dynamics using data extracted from public webcams. ISPRS Int. J. Geo-Inf. 2019, 8, 559. [CrossRef]

54. Mazeikaite, G.; O'Donoghue, C.; Sologon, D.M. The Great Recession, financial strain and self-assessed health in Ireland. Eur. J. Health Econ. 2019, 20, 579-596. [CrossRef]

55. Tuori, K.; Tuori, K. The Eurozone Crisis: A Constitutional Analysis; Cambridge University Press: Cambridge, UK, 2014; ISBN 1107729882.

56. Healy, T. The Impact of Brexit on Ireland's Housing Market; The Nevin Economic Research Institute: Dublin, Ireland, 2018.

57. McGrath, P. Brexit and Likely Implications for Ireland. SSRN J. 2016. [CrossRef]

58. Sorin, G.M.; Darker, C.; Whiston, L.; Donnelly-Swift, E.; Barry, J.; Kelly, B.D. Physical and Mental Health in Post-Recession Ireland: A Community Study; The Meath Foundation: Dublin, Ireland, 2018.

59. Szczepańska, A.; Gościewski, D.; Gerus-Gościewska, M. A GRID-Based Spatial Interpolation Method as a Tool Supporting Real Estate Market Analyses. ISPRS Int. J. Geo-Inf. 2020, 9, 39. [CrossRef]

60. Mitas, L.; Mitasova, H. Spatial interpolation. In Geographical Information Systems: Principles, Techniques, Management and Applications; Wiley: Hoboken, NJ, USA, 1999.

61. Simpson, G.; Wu, Y.H. Accuracy and effort of interpolation and sampling: Can GIS help lower field costs? ISPRS Int. J. Geo-Inf. 2014, 3, 1317-1333. [CrossRef]

62. South Dublin County Council's Online Consultation Portal. Lucan, Palmerstown \& Adamstown. Available online: https: / / consult.sdublincoco.ie/en/consultation/south-dublin-county-development-plan-2022-2028-strategic-issues-consultationbooklet/chapter/lucan-palmerstown-adamstown (accessed on 19 April 2021).

63. News, R. Quintain Gets Permission for 245 New Homes in Lucan. RTÉ [Online]. 16 July 2020. Available online: https: //www.rte.ie/news/business/2020/0716/1153622-quintain-ireland-new-lucan-homes/ (accessed on 19 April 2021).

64. Ongar, Dublin 15 Neighbourhood Guide-Information on Property, Local Amenities, Schools, Maps, Services and Transportation Links. Available online: https://www.myhome.ie/neighbourhood-guide/ongar/1438 (accessed on 19 April 2021).

65. Adamstown Development Gross Value Is at $€ 80$ Million. Available online: https://www.echo.ie/show/article/adamstowndevelopment-gross-value-is-at-80-million (accessed on 19 April 2021). 
66. Hesse, M.; Rafferty, M. Relational Cities Disrupted: Reflections on the Particular Geographies of COVID-19 for Small but Global Urbanisation in Dublin, Ireland, and Luxembourg City, Luxembourg. Tijdschr. Econ. Soc. Geogr. 2020, 111, 451-464. [CrossRef] [PubMed]

67. Moore-Cherry, N.; Bonnin, C. Playing with time in Moore Street, Dublin: Urban redevelopment, temporal politics and the governance of space-time. Urban Geogr. 2020, 41, 1198-1217. [CrossRef]

68. Kelly, A.; Tjeur, C. The National Deprivation Index for Health \& Health Services Research-Update 2013; Small Area Health Research Unit Department of Public Health \& Primary Care Trinity College Dublin: Dublin, Ireland, 2013.

69. Pratschke, J.; Haase, T. A longitudinal study of area-level deprivation in Ireland, 1991-2011. Environ. Plan. B Plan. Des. 2015, 42, 384-398. [CrossRef]

70. Murray, S. Here Are the Towns in Ireland with the Highest Household Incomes. Available online: https://www.thejournal.ie/ cso-malahide-4690048-Jun2019/ (accessed on 19 April 2021).

71. Darker, C.; Whiston, L.; Long, J.; Donnelly-Swift, E.; Barry, J. Health Assets and Needs Assessment (HANA) Tallaght, 2014; Trinity College Dublin, Adelaide Health Foundation and Tallaght Hospital: Dublin, Ireland, 2014.

72. Jenks, G.F. The data model concept in statistical mapping. Int. Yearb. Cartogr. 1967, 7, 186-190.

73. Van Ham, M.; Tammaru, T.; Ubarevičienè, R.; Janssen, H. Urban Socio-Economic Segregation and Income Inequality: A Global Perspective; Springer Nature: Basingstoke, UK, 2021.

74. Desmond, M.; Shollenberger, T. Forced Displacement from Rental Housing: Prevalence and Neighborhood Consequences. Demography 2015, 52, 1751-1772. [CrossRef] [PubMed]

75. Gomes, E.; Inácio, M.; Bogdzevič, K.; Kalinauskas, M.; Karnauskaitè, D.; Pereira, P. Future scenarios impact on land use change and habitat quality in Lithuania. Environ. Res. 2021, 197, 111101. [CrossRef]

76. Uesugi, M. Changes in Occupational Structure and Residential Segregation in Tokyo. In Urban Socio-Economic Segregation and Income Inequality; Springer Nature: Basingstoke, UK, 2021; p. 209.

77. Van Ham, M.; Tammaru, T.; Ubarevičienè, R.; Janssen, H. Rising inequalities and a changing social geography of cities. An introduction to the global segregation book. In Urban Socio-Economic Segregation and Income Inequality; Springer Nature: Basingstoke, UK, 2021.

78. Ng, M.K.; Lau, Y.T.; Chen, H.; He, S. Dual Land Regime, Income Inequalities and Multifaceted Socio-Economic and Spatial Segregation in Hong Kong. In Urban Socio-Economic Segregation and Income Inequality; Springer Nature: Basingstoke, UK, 2021; p. 113.

79. Kitchin, R.; Hearne, R.; O'Callaghan, C. Housing in Ireland: From crisis to crisis. SSRN Electron. J. 2015. [CrossRef]

80. Olofsson, T.; Andersson, S.; Sjögren, J.-U. Building energy parameter investigations based on multivariate analysis. Energy Build. 2009, 41, 71-80. [CrossRef]

81. Dadzie, J.; Runeson, G.; Ding, G. Determinants of sustainable upgrade for energy efficiency-The case of existing buildings in Australia. Energy Procedia 2018, 153, 284-289. [CrossRef]

82. Keely, R.; Lyons, R.C. Housing Prices, Yields and Credit Conditions in Dublin since 1945. J. Real Estate Financ. Econ. 2020. [CrossRef]

83. Lisi, G. Property valuation: The hedonic pricing model-location and housing submarkets. J. Prop. Invest. Financ. 2019, 37, 589-596. [CrossRef]

84. D'Amato, M.; Kauko, T. Advances in Automated Valuation Modeling; Springer International Publishing AG: New York, NY, USA, 2017. [CrossRef]

85. Del Giudice, V.; de Paola, P.; Francesca, T.; Nijkamp, P.J.; Shapira, A. Real estate investment choices and decision support systems. Sustainability 2019, 11, 3110. [CrossRef]

86. Anselin, L. Spatial Econometrics: Methods and Models; Springer Science \& Business Media: Berlin/Heidelberg, Germany, 2013; ISBN 9401577994.

87. Osland, L. An application of spatial econometrics in relation to hedonic house price modeling. J. Real Estate Res. 2010, 32, 289-320. [CrossRef]

88. Rabiei Dastjerdi, H. Making Invisible City Visible: A Solution for Mapping Hidden Socioeconomic Patterns in Tehran. Socio-Spatial Studies 2019, 3, 39-49. [CrossRef]

89. Gneiting, T.; Ševčíková, H.; Percival, D.B. Estimators of fractal dimension: Assessing the roughness of time series and spatial data. Stat. Sci. 2012, 27, 247-277. [CrossRef]

90. Eiter, T.; Mannila, H. Computing Discrete Fréchet Distance; Christian Doppler Laboratory for Expert Systems: Vienna, Austria, 1994.

91. Sharma, K.P.; Pooniaa, R.C.; Sunda, S. Map matching algorithm: Curve simplification for Frechet distance computing and precise navigation on road network using RTKLIB. Clust. Comput. 2019, 22, 13351-13359. [CrossRef] 